\title{
A novel culture method that sustains ERa signaling in human breast cancer tissue microstructures
}

Ana Luísa Cartaxo ${ }^{1,2+}$, Marta F. Estrada ${ }^{1,2+}$, Giacomo Domenici ${ }^{1,2}$, Ruben Roque ${ }^{3}$, Fernanda Silva ${ }^{4}$, Emilio J. Gualda ${ }^{5}$,

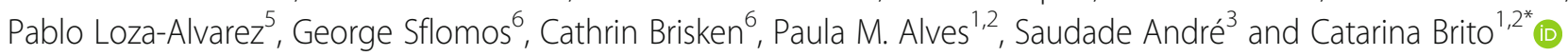

\begin{abstract}
Background: Estrogen receptor a (ERa) signaling is a defining and driving event in most breast cancers; ERa is detected in malignant epithelial cells of $75 \%$ of all breast cancers (classified as ER-positive breast cancer) and, in these cases, ERa targeting is the main therapeutic strategy. However, the biological determinants of ERa heterogeneity and the mechanisms underlying therapeutic resistance are still elusive, hampered by the challenges in developing experimental models recapitulative of intra-tumoral heterogeneity and in which ERa signaling is sustained. Ex vivo cultures of human breast cancer tissue have been proposed to retain the original tissue architecture, epithelial and stromal cell components and ERa. However, loss of cellularity, viability and ERa expression are well-known culture-related phenomena.
\end{abstract}

Methods: BC samples were collected and brought to the laboratory. Then they were minced, enzymatically digested, entrapped in alginate and cultured for 1 month. The histological architecture, cellular composition and cell proliferation of tissue microstructures were assessed by immunohistochemistry. Cell viability was assessed by measurement of cell metabolic activity and histological evaluation. The presence of ERa was accessed by immunohistochemistry and RT-qPCR and its functionality evaluated by challenge with 17- $\beta$-estradiol and fulvestrant.

Results: We describe a strategy based on entrapment of breast cancer tissue microstructures in alginate capsules and their long-term culture under agitation, successfully applied to tissue obtained from 63 breast cancer patients. After 1 month in culture, the architectural features of the encapsulated tissue microstructures were similar to the original patient tumors: epithelial, stromal and endothelial compartments were maintained, with an average of 97\% of cell viability compared to day 0 . In ERa-positive cases, fibers of collagen, the main extracellular matrix component in vivo, were preserved. ERa expression was at least partially retained at gene and protein levels and response to ERa stimulation and inhibition was observed at the level of downstream targets, demonstrating active ER signaling.

(Continued on next page)

\footnotetext{
* Correspondence: anabrito@ibet.pt

${ }^{\dagger}$ Ana Luísa Cartaxo and Marta F. Estrada contributed equally to this work.

${ }^{1}$ iBET, Instituto de Biologia Experimental e Tecnológica, Oeiras, Portugal

${ }^{2}$ Instituto de Tecnologia Química e Biológica António Xavier, Oeiras, Portugal

Full list of author information is available at the end of the article
}

C C The Author(s). 2020 Open Access This article is licensed under a Creative Commons Attribution 4.0 International License, which permits use, sharing, adaptation, distribution and reproduction in any medium or format, as long as you give appropriate credit to the original author(s) and the source, provide a link to the Creative Commons licence, and indicate if changes were made. The images or other third party material in this article are included in the article's Creative Commons licence, unless indicated otherwise in a credit line to the material. If material is not included in the article's Creative Commons licence and your intended use is not permitted by statutory regulation or exceeds the permitted use, you will need to obtain permission directly from the copyright holder. To view a copy of this licence, visit http://creativecommons.org/licenses/by/4.0/. The Creative Commons Public Domain Dedication waiver (http://creativecommons.org/publicdomain/zero/1.0/) applies to the data made available in this article, unless otherwise stated in a credit line to the data. 
(Continued from previous page)

Conclusions: The proposed model system is a new methodology to study ex vivo breast cancer biology, in particular ERa signaling. It is suitable for interrogating the long-term effects of anti-endocrine drugs in a set-up that closely resembles the original tumor microenvironment, with potential application in pre- and co-clinical assays of ERa-positive breast cancer.

Keywords: Cancer, Patient-derived cancer models, 17- $\beta$-estradiol, Estrogen receptor alpha, Fulvestrant, Encapsulation, Alginate

\section{Background}

Breast cancer $(\mathrm{BC})$ is the most commonly diagnosed cancer among women worldwide [1]. It is a heterogeneous disease with distinct biological features and clinical outcomes. Almost 75\% of diagnosed BC express estrogen receptor-alpha $(\mathrm{ER} \alpha)$, being classified as $\mathrm{ER} \alpha-$ positive $(\mathrm{ER}+) \mathrm{BC}[2]$. ER $\alpha$ acts as a ligand-dependent transcription factor for genes associated with cell survival, proliferation, and tumor growth [3]. Therefore, targeting the ER $\alpha$-signaling pathway is the main therapeutic strategy for the treatment of ER+ BCs. Nonetheless, the disease often progresses in $30 \%$ of the patients undergoing hormonal therapy due to resistance [2]. Thus, there is a need to select patients that would respond to endocrine therapy and to elucidate the molecular mechanisms behind endocrine resistance, as well as to identify biomarkers that predict drug response and resistance and novel therapeutic targets in resistant tumors.

When cultured in classical 2D monolayers, ER+ BC cell lines fail in recapitulating the typical intratumoral $\mathrm{ER} \alpha$ heterogeneity [4] and, due to cell confluency, cannot be kept continuously for more than 1 week [5], hampering the possibility to perform cycles of drug treatment for more than 1 week. Only a few ER+ cell lines can generate xenografts in mice, requiring supplementation with estrogen [6]. Recently, an estrogen supplementation-independent in vivo model was reported, based on intraductal implantation of ER+ tumor cells. The demonstration that the intraductal but not the mammary fat pad microenvironment favors epithelial malignant cells of the luminal subtype, consolidated the role of the tumor microenvironment (TME) in sustaining ER+ tumor cells [6]. Although there is a report showing that it is possible to propagate normal primary breast ER+ cells in 2D [7], there are no reports for propagation of primary ER+ $\mathrm{BC}$ cells using this culture system. In fact, ER+ $\mathrm{BC}$ primary cells cultured in $2 \mathrm{D}$ loose cellularity and ER $\alpha$ expression after a short culture period.

Ex vivo cultures have been explored to sustain ER+ malignant epithelial cells within the original BC microenvironment [8]. Typically, these models retain tissue architecture and heterogeneity for short periods of time, around 3 to 4 days of culture [7, 9]. Naipal et al. reported extension of culture time up to 7 days by exploring dynamic culture conditions [10]. Recently, Muraro et al. reported high cell viability and maintenance of ER expression up to 14 days in culture, when combining a collagen scaffold and a medium perfusion system [8]. Nonetheless, this methodology supports BC tissue maintenance by taking advantage of collagen scaffolds, biologically active animal-derived biomaterials which bring variability, as well as environmental and ethical concerns [11].

Here, we hypothesized that retention of the original microenvironment would favor the maintenance of ER+ $B C$ phenotype and ER $\alpha$ signaling. We implemented an ex vivo strategy based on the encapsulation of tissue microstructures in alginate, an inert biomaterial, combined with dynamic culture, aiming to maintain the original tissue structure, cell populations and extracellular matrix (ECM). We have recently shown that alginate microencapsulation of cancer cell spheroids and TME cellular components promotes tumor-stromal crosstalk and retention of secreted ECM components towards reconstruction of TME features [12, 13]. Therefore, we reasoned that by using alginate encapsulation to promote the original TME retention, while resourcing to dynamic culture to guarantee efficient diffusion of nutrients and oxygen, tissue microstructures would retain architectural integrity and potentially ER signaling.

\section{Methods}

\section{Ethics statement}

BC samples were collected at the Lisbon Oncology Hospital (Instituto Português de Oncologia de Lisboa Francisco Gentil - IPOLFG). The use of patient material was approved by the IPOFLG ethics committee and all patients have signed an informed consent form to agree to donate the material for research purposes. All tissues were anonymized before transfer to the laboratory for further processing.

\section{Cell culture}

MDA-MB-231 cell line was obtained from the American Type Culture Collection (ATCC). MDA-MB-231 cells were cultured in Dulbecco's Modified Eagle Medium 
(DMEM) high glucose and pyruvate medium (Gibco), supplemented with $10 \%(\mathrm{v} / \mathrm{v})$ fetal bovine serum (FBS, Gibco) and 1\% (v/v) Penicillin/Streptomycin (P/S, Gibco) at $37^{\circ} \mathrm{C}$ in $5 \% \mathrm{CO}_{2}$. Mycoplasma contamination was routinely checked.

\section{Collection and processing of patient material}

This study was elaborated on treatment-naïve patientderived $\mathrm{BC}$ tissue. The method for processing and culture was successfully applied to 63 female breast tumors (Table 1). Tumor samples were collected during surgery and immediately submerged in phenol red-free DMEM/ F-12 (Gibco), supplemented with 1\% (v/v) P/S (Gibco) and $10 \%(\mathrm{v} / \mathrm{v})$ FBS (Gibco). Samples were kept at $4{ }^{\circ} \mathrm{C}$ and transported to the laboratory within 1 to $3 \mathrm{~h}$ after surgery (Fig. 1a). Sixty-three BC samples were collected, with an average weight of $315 \pm 225 \mathrm{mg}$ (Figure S1).

Tissue samples were mechanically dissociated with two surgical scalpels to obtain pieces of 1 to $2 \mathrm{~mm}$ of diameter. Subsequently, the minced tissue was resuspended in phenol red-free DMEM/F-12, HEPES medium

Table 1 Clinico-pathological parameters of the breast cancer patients. pT: primary tumor; pN: primary node

\begin{tabular}{lll}
\hline Clinico-pathological parameters & $(\mathrm{n})$ & \\
\hline Female tumor samples & 63 & \\
Mean age at diagnosis & $62(42-89)$ \\
Hormone receptors & (n) & Percentage of tumors \\
ERa status & 59 & 94 \\
PR status & 51 & 81 \\
HER2 status & 11 & 17 \\
Triple negative status & 1 & 2 \\
Histological subtype & (n) & Percentage of tumors \\
Invasive breast carcinoma of & 51 & 81 \\
no-special type (NST) & & \\
Lobular & 10 & 16 \\
Mucinous & 2 & 3 \\
Tumor grade & (n) & Percentage of tumors \\
1 & 2 & 3 \\
2 & 50 & 79 \\
3 & 9 & 14 \\
Not defined & 2 & 3 \\
Tumor size & (n) & Percentage of tumors \\
pT1 & 38 & 60 \\
pT2 & 22 & 35 \\
pT3 & 3 & 5 \\
Lymph node involvement status & (n) & Percentage of tumors \\
pN0 & 41 & 65 \\
pN2 & 21 & 33 \\
\hline & 1 & 2 \\
\hline
\end{tabular}

(Gibco) containing $0.09 \mathrm{U} / \mathrm{mL}$ of Collagenase A (Roche), $30 \mathrm{U} / \mathrm{mL}$ of Benzonase (Merck Millipore), 10\% (v/v) FBS (Gibco) and 1\% (v/v) P/S (Gibco). Digestion was performed in an incubator at $37^{\circ} \mathrm{C}$, in a humidified atmosphere containing $5 \% \mathrm{CO}_{2}$. After $12-15 \mathrm{~h}$ of enzymatic digestion, tumor fragments (tissue microstructures, average of $1 \mathrm{~mm}^{3}$ ) were sedimented by centrifugation at $100 \mathrm{x} \mathrm{g}$ for $5 \mathrm{~min}$ at $4{ }^{\circ} \mathrm{C}$ and washed with PhosphateBuffered Saline (PBS; Life Technologies) (Fig. 1a).

\section{Tissue microstructure encapsulation and culture}

Tissue microstructures were entrapped in alginate, employing protocols previously developed by our team [13]. Briefly, tissue microstructures were dispersed in 1 $\mathrm{mL}$ of $2 \%(\mathrm{w} / \mathrm{v})$ of Ultrapure $\mathrm{Ca}^{2+}$ MVG alginate (UP MVG NovaMatrix, Pronova Biomedical, Oslo, Norway) dissolved in $\mathrm{NaCl} 0.9 \%(\mathrm{w} / \mathrm{v})$. Encapsulation was performed using an electrostatic bead generator (Nisco VarV1, Zurich, Switzerland), with an air flow rate of 10 $\mathrm{mL} / \mathrm{h}$, at $5.3 \mathrm{~V}$ under air pressure of $1 \mathrm{bar}$, using a 1.1 $\mathrm{mm}$ nozzle. The resulting alginate droplets containing tissue micro fragments (1-2 fragments/droplet) were cross-linked in a $100 \mathrm{mM} \mathrm{CaCl}_{2} / 10 \mathrm{mM}$ HEPES (pH 7.4) solution for $10 \mathrm{~min}$, washed three times in a $0.9 \%(\mathrm{w} / \mathrm{v})$ $\mathrm{NaCl}$ solution and finally equilibrated in culture medium. Encapsulated tissue microstructures were then transferred into 6-well plates and placed under orbital shaking $(100 \mathrm{rpm})$, in a humidified incubator, with $5 \%$ $\mathrm{CO}_{2}$. Encapsulated tissue microstructures cultures were maintained up to 30 days, with $50 \%$ medium exchange every 3-4 days (Fig. 1a). Cultures were maintained in human mammary epithelial cell (HMEC) culture medium: DMEM/F12 phenol red free with $1 \% \mathrm{P} / \mathrm{S}(\mathrm{v} / \mathrm{v})$ solution (both from Life Technologies), $5 \mathrm{ng} / \mathrm{mL}$ Epidermal Growth Factor (EGF), $10 \mu \mathrm{g} / \mathrm{mL}$ Insulin, $0.5 \mu \mathrm{g} / \mathrm{mL}$ Hydrocortisone, $0.5 \mu \mathrm{g} / \mathrm{mL}$ Transferrin, 0.1 $\mathrm{mM}$ Isoprotenol, $0.1 \mathrm{mM}$ Ethanolamine, $0.1 \mathrm{mM} \mathrm{O}$ Phosphoethanolamine, $\quad 70 \mu \mathrm{g} / \mathrm{mL}$ Bovine Pituitary Extract (all reagents are from Sigma-Aldrich) and $100 \mu \mathrm{g} / \mathrm{mL}$ Primocin (InvivoGen Europe). Nonencapsulated tissue microstructures were maintained under the same culture conditions. Encapsulated tissue microstructures were assessed for cell viability, architecture, cell populations, ECM deposition, ER $\alpha$ presence and signaling, as described below; the extent of assessment performed for each sample was determined by the initial sample size.

\section{Cell viability assessment}

Cell viability was correlated with resazurin reduction capacity (PrestoBlue ${ }^{\mathrm{Tm}}$ Cell Viability Reagent, ThermoFischer Scientific), according to manufacturer's instructions. Encapsulated and non-encapsulated samples were incubated for $1 \mathrm{~h}$ with PrestoBlue reagent in culture 
a)

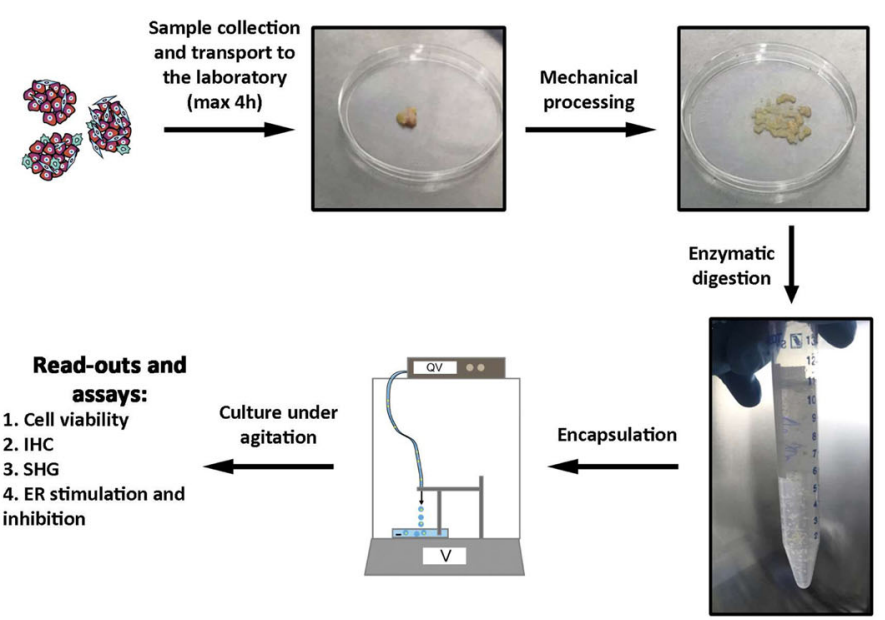

b)
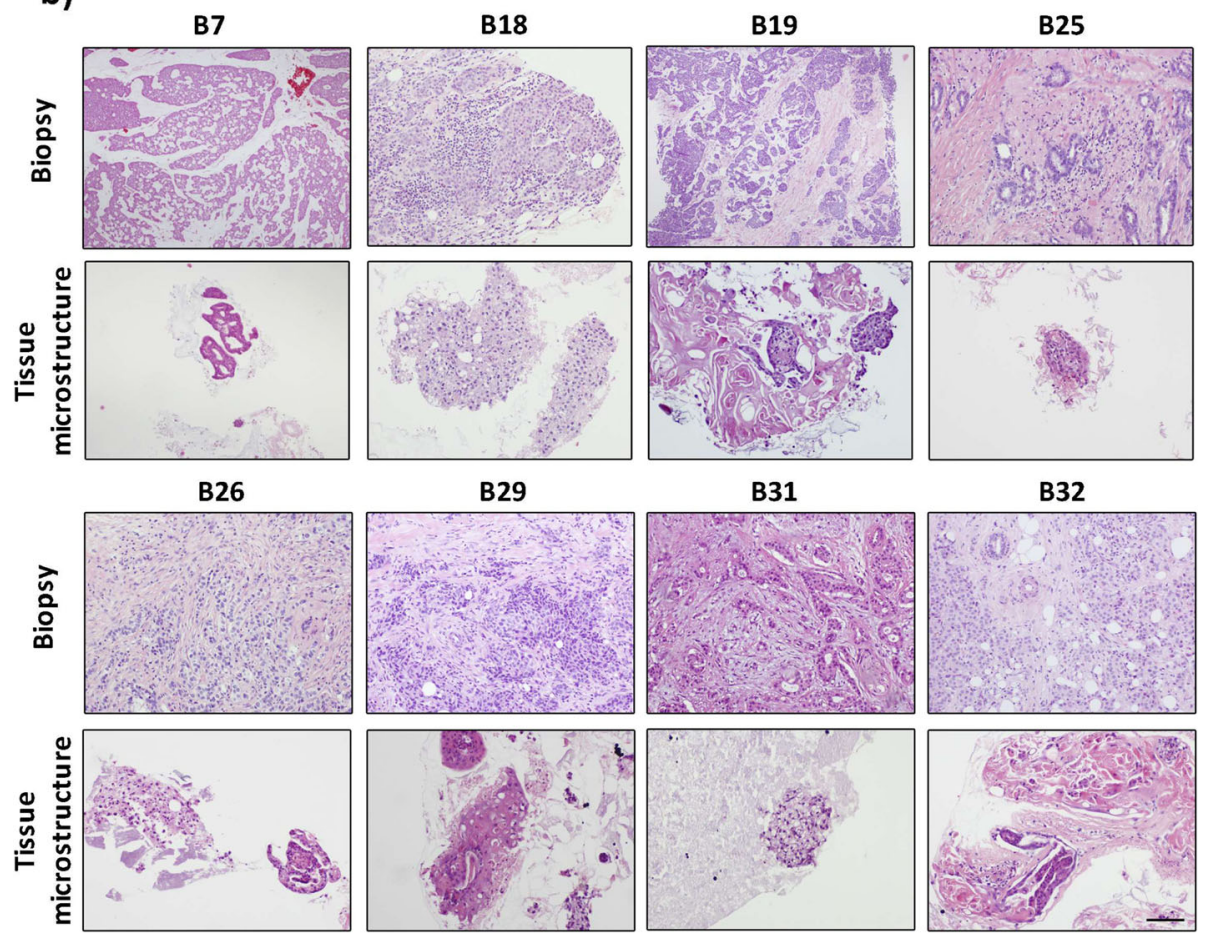

Fig. 1 Alginate encapsulated tissue microstructures maintained parental tumor architecture. a Experimental workflow for the establishment of long-term cultures of BC patient-derived tissue microstructures: samples were collected at the hospital and brought to the laboratory within 1-3 $\mathrm{h}$ of surgery. Tissue samples were mechanical processed and subjected to mild enzymatic digestion. The obtained BC tissue microstructures were encapsulated in alginate and cultured for up to 1 month. Along culture, tissue microstructures were interrogated: cell viability assessment, immunohistochemistry analysis (IHC), Second Harmonic Generation (SHG) microscopy and estrogen receptor a (ER) stimulation and inhibition were performed. b Hematoxylin and eosin of biopsy (top row) and corresponding encapsulated microstructures at 1 month of culture (bottom row) (scale: $200 \mu \mathrm{m})$

medium, at $37^{\circ} \mathrm{C}$, in a humidified atmosphere incubator, containing $5 \% \mathrm{CO}_{2}$. Medium was sampled in quadruplicate and resazurin reduction evaluated by fluorescence detection (ext/em 560/590 nm) in a fluorimeter (Infinite $^{\circ} 200$ PRO NanoQuant, Tecan Trading AG). Resazurin reduction was evaluated for 1 month, once a week. Data is represented as fold-change in resazurin reduction relative to the first week of the assay.

\section{Histological and immunohistochemistry analysis}

Samples were collected after 1 month of culture and alginate capsules were de-polymerized with $50 \mathrm{mM}$ EDTA 
for $5 \mathrm{~min}$ at RT. De-encapsulated tissue microstructures were centrifuged at $300 \mathrm{x} \mathrm{g}, 5 \mathrm{~min}$ at $4{ }^{\circ} \mathrm{C}$, washed with PBS, fixed with formol overnight at RT. For paraffin cell-block preparation, the cellular suspension was centrifuged for $5 \mathrm{~min}$, at $1270 \mathrm{x} \mathrm{g}$, resuspended in $10 \%(\mathrm{v} / \mathrm{v})$ buffered formalin (VWR BDH Chemicals, ref. 9713.9010) to which a drop of haematoxylin was added for specimen counterstain, and stored in a $1.5 \mathrm{~mL}$ microtube. The remaining supernatants were subjected to a second centrifugation, for $5 \mathrm{~min}$, at 1990x g. The supernatant was discarded and four drops of liquefied HistoGel (Thermo Scientific, ref. HG-4000-012) were added to the pellet. After gentle homogenization with a Pasteur pipette and centrifugation for $2 \mathrm{~min}$, at $1990 \mathrm{x} \mathrm{g}$, the sample was placed at $-20^{\circ} \mathrm{C}$ for 5 min to solidify. The cone shape solidified sample was removed from the microtube, cut along the meridional section and placed in a biopsy cassette, which was then immerged in a container with buffered formalin to be included in paraffin. After processing, the samples were sectioned and stained with hematoxylin and eosin (H\&E) (Dako CoverStainer for H\&E equipment, Agilent, Santa Clara, CA, USA). Paraffin blocks were sectioned $(3 \mu \mathrm{m})$ for $\mathrm{H} \& \mathrm{E}$ and immunohistochemical staining. Immunohistochemistry (IHC) was carried out using standard procedures implemented at IPOLFG; antigen retrieval was done using Cell Conditioning 1 (CC1, Ventana) and tissue staining was performed using an automated IHC/ISH slide staining Ventana BenchMark Ultra (all from Ventana Medical Systems, Inc). Antibodies and details on the protocol used are indicated in Table S1. Histologic analysis was performed by an expert breast pathologist. IHC analysis was performed for cultures derived from BC samples of 18 patients. Due to primary material limitations, E-cadherin, CD45, ki-67, ER and p63 levels were assessed in 8 different samples; vimentin was assessed in 9 and CD31 in 2.

\section{Multi-photon microscopy}

Fibrillar Collagen was assessed by multi-photon microscopy. After 1 month in culture, encapsulated tissue microstructures were collected, fixed in PFA $4 \%(\mathrm{w} / \mathrm{v})$ in PBS for $30 \mathrm{~min}$, washed thrice with PBS and kept at $4{ }^{\circ} \mathrm{C}$ until further analysis. Samples were imaged with twophoton-excited fluorescence (TPEF), second harmonic generation (SHG) and infrared (IR) absorption in a home-made multiphoton microscope [14]. The excitation laser was a Ti:Sapphire at $810 \mathrm{~nm}$ and the laser power, at entrance of the microscope, was of $40 \mathrm{~mW}$. Initial tests performed with $100 \mathrm{~mW}$ resulted in no observable sample damage. The Illumination objective was an Olympus $25 \times 1.05 \mathrm{~W}$. The TPEF signal was collected through a photomultiplier tube (PMT) in backward direction (using a LP410 filter) while IR absorption and
SHG (405/25 filter) were collected in forward direction through a Nikon $25 \times 1.10 \mathrm{~W}$ objective, using a photodetector and a PMT respectively. During acquisition, 34 images were averaged to reduce noise.

\section{Challenge with ERa agonist and antagonist}

At day 28-30 of culture, encapsulated $\mathrm{BC}$ tissue microstructures were stimulated with $10 \mathrm{nM} 17-\beta$-estradiol (Sigma-Aldrich). Three days before $17-\beta$-estradiol challenge, encapsulated tissue microstructures were washed thrice with PBS and were then kept in phenol red-free HMEC medium without insulin, hydrocortisone and EGF, which may trigger activation or phosphorylation of ER [15-20]. Alternatively, a 50\% culture medium exchange was performed by the time of $17-\beta$-estradiol challenge. Control wells were also included, in which only ethanol (17- $\beta$-estradiol vehicle) was added to a final concentration of $0.001 \%(\mathrm{v} / \mathrm{v})$. After $24 \mathrm{~h}$ of exposure, encapsulated tissue microstructures were collected and alginate dissolved (as described in section 6 of Materials and Methods). Challenge with 17- $\beta$-estradiol was performed in encapsulated microstructures derived from 16 different patients, of which 9 in depleted medium and 7 in complete medium.

Encapsulated tissue microstructures were also challenged with fulvestrant (ICI 182,780), an ER antagonist and degrader [20-22]. For these experiments, 3-5 days after encapsulation HMEC medium was supplemented with $1 \mu \mathrm{M}$ fulvestrant (Tocris Bioscience). Twice a week, half volume of culture medium was changed and fulvestrant was replenished to keep a constant concentration. After 2 weeks, samples were centrifuged at $300 \mathrm{x} \mathrm{g}, 5 \mathrm{~min}$ at $4{ }^{\circ} \mathrm{C}$, washed with PBS and processed for IHC (as detailed above) or RT-qPCR analysis. Samples for RTqPCR were stored in RNAlater Stabilization Solution (Roche), according with the manufacturer's instructions, until further analysis; samples for western blot were snap frozen at $-80^{\circ} \mathrm{C}$. Challenge with fulvestrant was performed in encapsulated microstructures derived from 8 different patients, of which 7 were evaluated by RTqPCR and 3 by Western Blot.

\section{Gene expression analysis}

Tissue microstructures were thawed, total RNA was extracted in a tissue lyser (Precellys Evolution Homogenizer, Bertin Instruments) and purified using the RNAeasy Kit (Qiagen), according to the manufacturer's instructions. Reverse transcription was performed using Sensiscript RT kit (Qiagen), also according with the manufacturer's instructions. qPCR was performed in triplicates, using the SYBR green I Master kit (Roche), in a LightCycler 480 II (Roche). We evaluated expression of ER $\alpha$ (ESR1) and its downstream target genes, $p S 2$, $A R E G$ and PGR [23], and of two housekeeping genes, 
RPL22 [12] and 36B4 [23]. Primer sequences are provided in Table S2. Due to the scarcity of ER $\alpha$ negative $\mathrm{BC}$ samples, a ER $\alpha$ and PR negative BC cell line, MDAMB-231, was employed as basal expressing control [24]. Results are shown as fold change in mRNA amount compared to the vehicle control (CTRL), calculated according to the $2^{-\Delta \Delta \mathrm{Ct}}$ method [25], considering a geometric mean of the 2 housekeeping genes used.

\section{Western blot analysis}

Samples were thawed, resuspended in Laemmli Buffer (20\% Glycerol, 4\% SDS in $100 \mathrm{mM}$ Tris Buffer, pH 6.8) and lysed in a Tissue homogenizer (Precellys Evolution, Bertin Instruments). BC Microstructure lysates were recovered, sedimented to remove cell debris, sonicated and stored at $-80^{\circ} \mathrm{C}$ until use.

Protein quantification was performed in a Nanodrop ND-2000C (Thermo Scientific). Proteins were denatured and loaded in a electrophoresis gel (NuPAGE 4-12\% Bis-Tris Gel) under reducing conditions for $50 \mathrm{~min}(200$ $\mathrm{V})$ and then electrophoretically transferred using a wet transfer system (Bio-Rad, $30 \mathrm{~V}, 18 \mathrm{~h}, 4^{\circ} \mathrm{C}$ ) into nitrocellulose membranes. Membranes were blocked for $1 \mathrm{~h}$ in TBS with $0.1 \%(\mathrm{w} / \mathrm{v})$ Tween $20,5 \%(\mathrm{w} / \mathrm{v})$ non-fat dried milk and further incubated with the primary antibodies (Mouse anti-Human ER $\alpha, 1 D 5$ Clone, Dako, final dilution 1:500; Rabbit anti- $\beta$ tubulin, H-235, SC-9104, SantaCruz, final dilution 1:1000, used as loading control) and respective secondary HRP-conjugated secondary antibodies (Sheep anti Mouse IgG NA931; Donkey anti Rabbit IgG NA934; GE Healthcare, final dilution 1: 20000). Membranes were developed using Amersham ECL Select Western Blot Detection Reagent (GE Healthcare) and visualized using a ChemiDoc System (BioRad).

\section{Statistical analysis}

Statistical analysis was performed using GraphPad Prism version 6.0 (GraphPad Software). Data were analyzed as indicated in the figure legends. The Mann-Whitney test was performed to evaluate statistical difference between conditions. Data are presented as mean $\pm \mathrm{SD}$, unless otherwise specified.

\section{Results}

\section{Alginate encapsulated tissue microstructures maintain parental tumor tissue characteristics for at least one month of culture}

To establish an ER+ BC ex vivo model, we investigated the possibility of retaining the TME and consequently $E R \alpha$ signaling of patient-derived tissue microstructures immobilized within alginate capsules and cultured under agitation (Fig. 1a). Encapsulated tissue microstructures were cultured for up to 30 days, showing high cell viability, as indicated by maintenance of resazurin reduction capacity along culture time ( $97 \pm 28 \%$ by the end of week 4 , relatively to the beginning of the culture, Figure S2a). Moreover, detection of extracellular lactate in culture medium (data not shown), as an indicator of high metabolic activity [26], corroborated the high cell viability within the encapsulated tissue microstructures.

The original tumors were very heterogeneous, not only between but also within patients (Fig. 1b): tissue architecture varied in epithelial versus stromal content, cell organization and on the presence/absence of immune cells (CD45+ cells). A complete mixture of malignant epithelial cells and stromal cells was rarely observed. Instead, there were islets of tumor cells surrounded by multiple stromal cells (Fig. 1b, upper panels). These histopathological characteristics were maintained in encapsulated tissue microstructures cultured for a month (Fig. 1b, lower panels). By day 30 of culture, Ecadherin, vimentin, CD31 and CD45 were immunohistochemically-detected (Fig. 2a). The detection of membranous E-cadherin indicated that carcinoma cells maintained the typical cell-cell adhesions and differentiated phenotype [27]. On the other hand, vimentin detection confirmed the presence of stromal cells. CD45, also known as leucocyte common antigen, is a transmembrane glycoprotein present in all nucleated cells of the hematopoietic lineage [28] and has been broadly used to assess immune cell population presence in breast tissue, such as tumor-infiltrating lymphocytes [29-31]. CD $45^{+}$cells were detected in 5 out of the 8 cases which presented immune cells in the original tissue (Fig. 2a). In two analyzed tissue microstructures, CD31 positivity confirmed the presence of endothelial cells (Fig. 2a). Absence of cells positive for the basal/myoepithelial marker p63 was observed similarly to the original tumors (Figure S2b). Ki67-positive cells were also detected at different levels, indicating the presence of proliferating cells even after 1 month of culture (Fig. 2b). Although at low levels, this is consistent with the parental tissues, where the median of proliferating cells was $20 \%(\mathrm{Q} 1=15$; $\mathrm{Q} 3=30$ ). Second harmonic generation analysis (SHG) of encapsulated $\mathrm{BC}$ tissue microstructures revealed dense and organized/fibrillar collagen fibers in peripheral regions of the samples analyzed, surrounding areas of cellularity (Fig. 3). As a culture control, non-encapsulated tissue microstructures were cultured in parallel. A significant decrease in resazurin reduction ability after 3-4 weeks of culture was observed, suggesting a reduced cell viability of these cultures. Remarkably, cell viability was increased in encapsulated versus non-encapsulated tissue microstructures (Figure S2c).

Altogether, we were able to extend the lifespan of $\mathrm{BC}$ explant cultures for up to 1 month whilst maintaining tissue architecture, the different cell types of the BC microenvironment, and cell viability. 


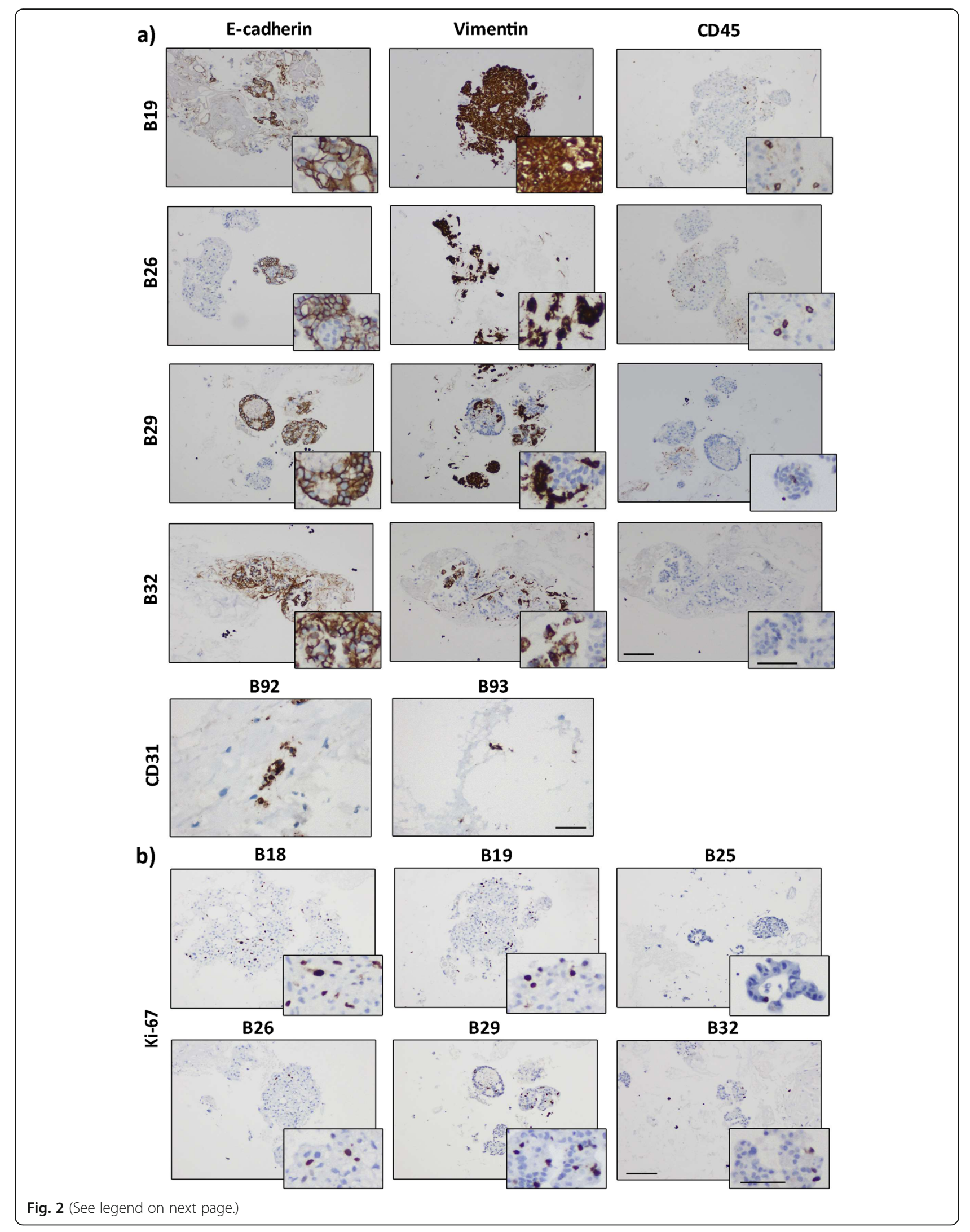


(See figure on previous page.)

Fig. 2 Alginate encapsulated tissue microstructures maintained cell populations and contained proliferating cells. a Immunohistochemistry analysis of: E-cadherin (epithelial cells); vimentin (stromal cells); CD45 (immune cells); CD31 (endothelial cells) at 1 month of culture $\mathbf{b}$ Immunohistochemistry analysis of Ki-67 (cell proliferation) of encapsulated microstructures at 1 month of culture (scale bars: $200 \mu \mathrm{m}$ for low magnification and $100 \mu \mathrm{m}$ for high magnification)

\section{ERa expression and functionality are sustained over 1} month of culture

After 1 month in culture, ER+ carcinoma cells were still detected in the encapsulated tissue microstructures by IHC analysis (Fig. 4a), typically in lesser extent that in the original sample. When sample material was not sufficient for IHC evaluation, mRNA was quantified, relatively to MDA-MB-231, a human cancer cell line which does not express ER $\alpha$ nor PR [24] (Figure S3a). All samples presented higher expression of the ER $\alpha$ gene (ESR1) than MDA-MB-231 cells, indicating ER $\alpha$ gene expression after 1 month of culture (Figure S3b and Figure S5).
To assess ER $\alpha$ function, encapsulated tissue microstructures derived from ER+ BC from 9 distinct patients were stimulated with $10 \mathrm{nM} 17-\beta$-estradiol for $24 \mathrm{~h}$ and the mRNA levels of the ER target genes evaluated: protein PS2 (also known as Trefoil Factor 1 -TFF1-, pS2), progesterone receptor $(P G R)$ and amphiregulin (AREG) [23]. AREG and PGR were upregulated upon challenging with 17- $\beta$-estradiol compared to vehicle-controls (mean fold increase in AREG and PGR expression of $3.4 \pm 5.6$ and $6.3 \pm 11$ respectively, Fig. 4b, Figure S4a). Strikingly, we detected a generalized upregulation of $p S 2$ (in 7 out of 9 tissue microstructures), with a mean fold increase in gene expression of $45 \pm 45$, compared to the vehicle-

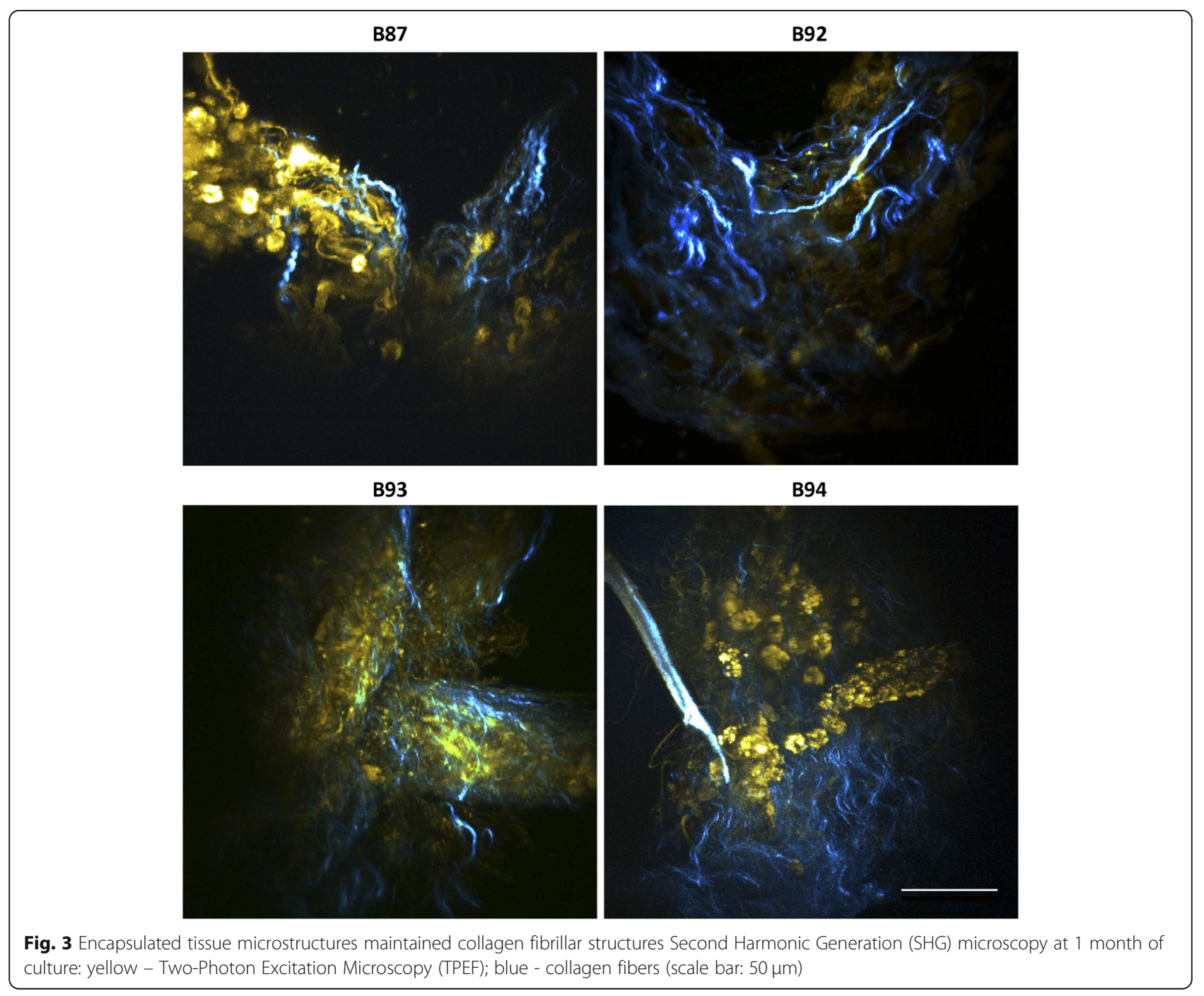



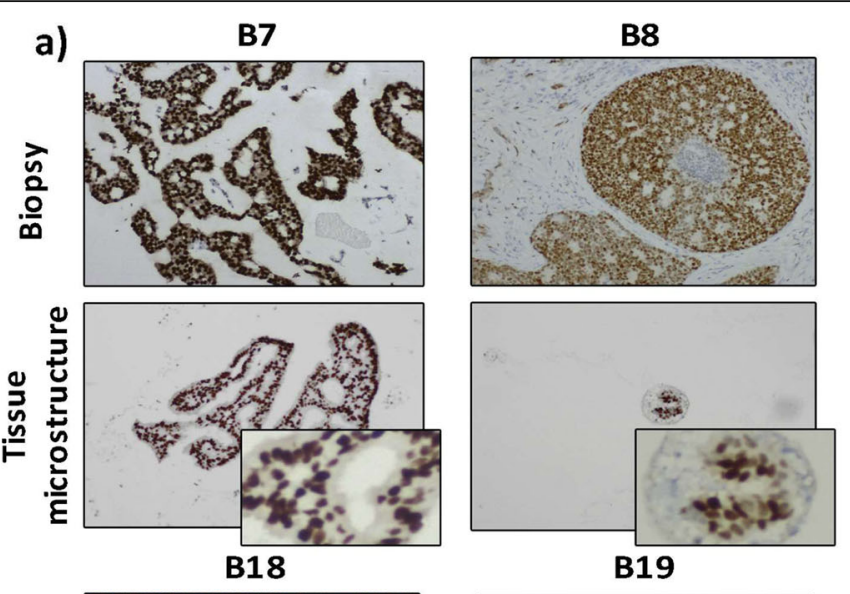

b)
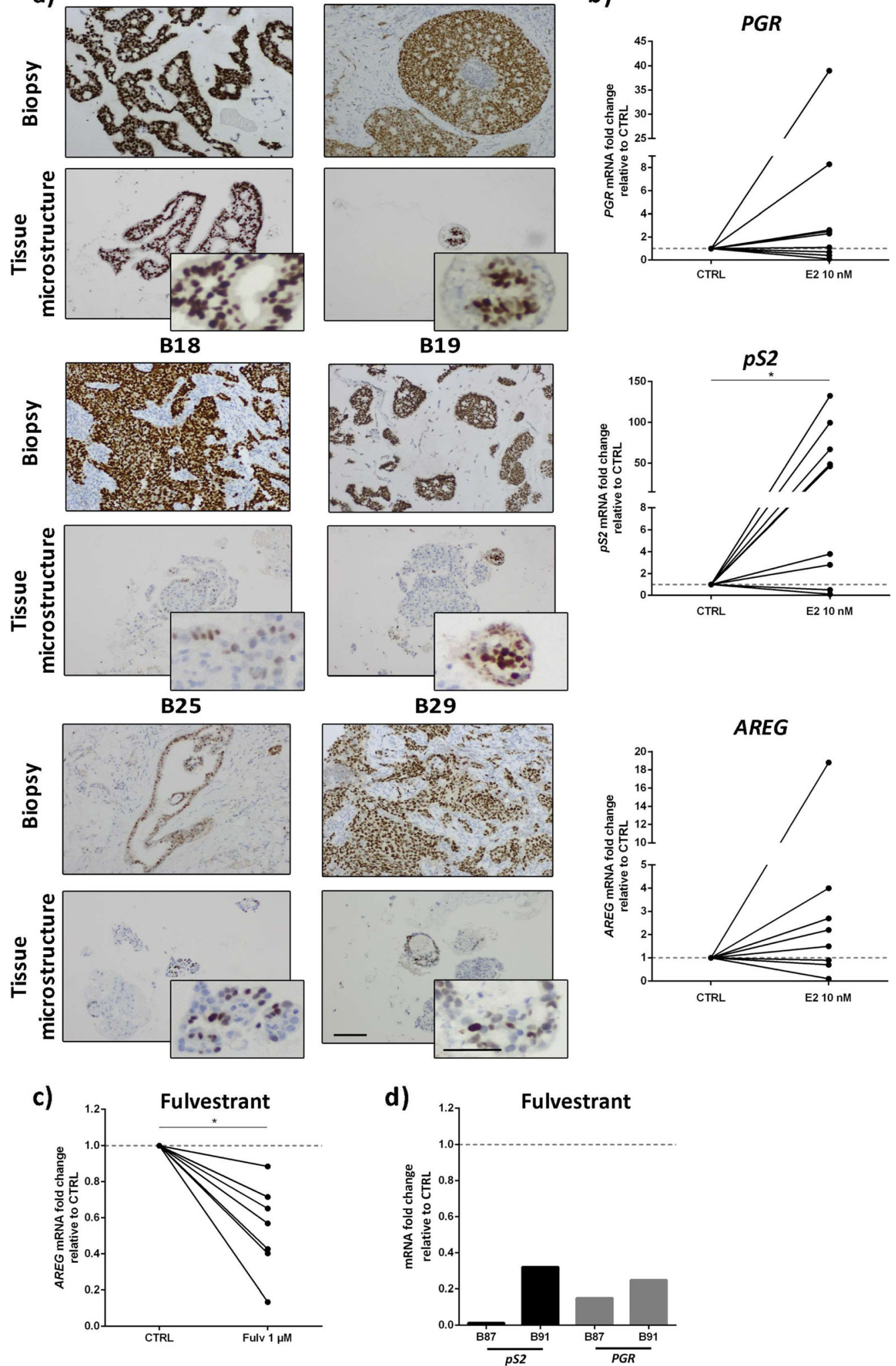

Fig. 4 (See legend on next page.) 
(See figure on previous page.)

Fig. 4 Estrogen Receptor a (ER) expression and functionality were maintained in alginate encapsulated tissue microstructures up to 1 month of culture. a Immunohistochemistry detection of ER in biopsy (top row) and encapsulated tissue microstructures culture for a month (bottom row) (scale bars: $200 \mu \mathrm{m}$ for low magnification and $100 \mu \mathrm{m}$ for high magnification). b Encapsulated tissue microstructures were cultured for 3 days in depleted medium and stimulated with 17- $\beta$-estradiol; expression of ER downstream target genes was assessed by RT-qPCR (amphiregulin - AREG, progesterone receptor - $P G R$ and protein PS2 - $p S 2, N=9$ ). Data are shown as fold change in gene expression upon 17- $\beta$-estradiol challenge relatively to vehicle-exposed control (CTRL). c, $\mathbf{d}$ Encapsulated tissue microstructures were cultured for 3-5 days in complete medium, before challenge with fulvestrant for 2 weeks; ER downstream targets were assessed by RT-qPCR (AREG, PGR and pS2, N=7). Data are shown as fold change in gene expression upon fulvestrant challenge relatively to vehicle-exposed control. Statistical analysis was performed by the MannWhitney test $\left({ }^{*} p\right.$-value $\left.<0.001\right)$

treated control (Fig. 4b, Figure S4a and Figure S5). In general, there was a trend for a positive correlation between ESR1 basal expression and the expression of the three ER target genes upon estrogen challenge (Figure S4b, $R>0$ by Pearson Correlation), even though not significant, probably due to the intrinsic variability of primary tumors and the sample size. Tissue microstructure cultures derived from ER-negative BC tumors were also treated with $17-\beta$-estradiol and no upregulation of ER downstream genes was observed (Figure S4c). This data further corroborates that the original phenotype was maintained in culture. A different set of encapsulated tissue microstructures, derived from $7 \mathrm{ER}+\mathrm{BC}$ samples, were maintained in HMEC medium until 17$\beta$-estradiol challenge. These showed a mild stimulation of ER $\alpha$ target genes (on average, 2.3-, 1.8- and 1.2-fold increase relatively to vehicle control for $p S 2, P G R$ and AREG, respectively, Figure S4d).

To further confirm intact ER $\alpha$ signaling in encapsulated tissue microstructures, cultures derived from additional ER+ BC samples were exposed to fulvestrant (or ICI 182,780), a ER $\alpha$ full antagonist [32] widely used in endocrine therapy [33]. After 2 weeks of exposure, a generalized down regulation of AREG compared to vehicle controls was observed (Fig. 4c). For two of the tumors, we also evaluated $P G R$ and $p S 2$ response and observed a strong reduction of mRNA levels compared to vehicle controls (Fig. 4d). Additionally, we assessed ER $\alpha$ protein levels in three of the tumors and observed a tendency for reduction compared to vehicle control conditions (Figure S6). Collectively, these results indicate that $E R \alpha$ is expressed in encapsulated tissue microstructures derived from $\mathrm{ER}+\mathrm{BC}$ samples and can respond to stimulation and inhibition.

\section{Discussion}

$E R \alpha$ signaling is considered a defining and driving event contributing to ER+ BC carcinogenesis; ER $\alpha$ overexpression in primary tumors has been linked to disease progression, influencing patient survival [34-36]. Nonetheless, approximately $30 \%$ of patients with $\mathrm{ER}+\mathrm{BC}$ fail to respond to endocrine therapy [2]. Several reports have shown the intricate relation between response to therapy and TME components, such as fibroblasts [37-39] and
ECM components [40, 41]. Therefore, it is paramount to define the biological determinants of ER $\alpha$ intra-tumoral heterogeneity and the mechanisms underlying therapeutic resistance. However, this knowledge has been hampered by the challenges in developing experimental models recapitulative of intra-tumoral ER $\alpha$ heterogeneity and in which ER $\alpha$ signaling is sustained, essential to address long-term effects of tumorstromal interactions in ER $\alpha$ signaling and drug response mechanisms against ER.

Here, we propose a culture strategy in which patientderived tissue microstructures retain $\mathrm{ER}+$ carcinoma cells for at least 1 month of culture; of note, these cells still respond to ER stimulation and inhibition, therefore constituting a functional ex vivo model of ER-positive BC. Tissue microstructures, that were entrapped in alginate capsules and cultured under dynamic conditions, maintained high cellularity and low levels of tumor cell proliferation, as reported for human ER+ BC [42], and parental tissue architecture (including epithelial, stromal and endothelial cell compartments and deposited fibrillar collagen). Although all interrogation was limited to 1 month of culture, as we have not detected signs of tissue microstructure decline in cell viability up to that timepoint, we conjecture that the lifespan of encapsulated tissue microstructures could be extended for even longer periods.

We hypothesized that using tissue microstructures within the millimeter size range would be more favorable to attain an accurate representation of intratumoral heterogeneity and TME, than more miniaturized ex vivo models. To overcome the major limitations of ex vivo cultures - the reduced lifespan and zonation due to diffusional gradients [43], we resourced to dynamic culture conditions. Agitation improves mass transfer, promoting nutrient and oxygen diffusion, reducing the formation of gradients typically observed for tissue microstructures within the above mentioned size range $[44,45]$. Moreover, we encapsulated in alginate, a biocompatible, inert hydrogel [46] since it has defined composition and confers support and protection from agitation-induced shear stress $[13,47,48]$. This contributes to the preservation of tissue architecture and cell viability, but also promotes the built-up of relevant cell 
microenvironment factors. In fact, we have previously shown that cells entrapped in alginate capsules, and cultured under agitation, accumulate secreted soluble factors (e.g., cytokines) and ECM components, promoting homotypic and heterotypic cellular crosstalk, cell migration and reconstruction of cancer-related microenvironments [12, 13], such as an immunosuppressive microenvironment in a non-small cell lung cancer model [12]. In terms of ECM components, we not only observed the maintenance of TME cellular components in the encapsulated tissue microstructures, such as the stromal cells, which are involved in the secretion of collagen [49], but also ECM components as collagen fibers. These were detected by SHG microscopy, a technique broadly applied to BC tissue [50]. In all the encapsulated tissue microstructures analyzed fibrillar collagen presence was observed. Increased collagen density has been shown to directly promote $\mathrm{BC}$ tumorigenesis [51]. Moreover, collagen is strongly associated with mammographic density used as a measurement of risk of $\mathrm{BC}$ [52] and is responsible for drug resistance since it prevents the penetration of therapeutic agents, such as antibodies [53].

The preservation of tumor heterogeneity and TME are critical to closely mimic the in vivo situation $[4,54]$. We observed a high degree of heterogeneity between distinct parental tissues - not only the levels of ER-positivity were different, but also the percentages and physical distribution of carcinoma and stromal cells - that were recapitulated in the derived tissue microstructures. In 5 out of 8 tissue microstructure cultures derived from tumors with immune cell infiltrate, CD45-positive cells were retained even after 1 month of culture, although in low amounts. This is in accordance with the typically low frequency of immune cell infiltrates in ER+ tumors [55].

After 1 month in culture, p63 was not detected in tissue microstructures, in accordance with what is reported for luminal BC. The myoepithelial marker p63 is present in basal cells of a variety of healthy epithelial tissues [56], such as in normal breast tissue. However, its expression in $\mathrm{BC}$ is rare $[56,57]$. On the other hand, tissue microstructures presented low levels of Ki-67; in fact, $E R \alpha$-positive subtypes have lower proliferative indexes than other BC subtypes [58]. The intrinsic low levels of cell proliferation and the reduced amount of patient tissue available to set-up tumor microstructure cultures, limit their application in high throughput assays.

The maintenance of ER+ cells in culture is a major accomplishment, as ER $\alpha$ ablation ex vivo has been a major issue in $\mathrm{ER}+\mathrm{BC}$ research [59]. The sustained expression of $E R \alpha$ is pivotal for the study of the luminal A subtype of $B C$, as cell proliferation is ER-dependent and targeted therapies usually rely on prolonged treatment with ER $\alpha$ antagonists [60]. After 1 month in culture, we detected ER+ cells in the encapsulated tissue microstructures, typically in a less extent than in the original tumor. ER $\alpha$ functionality was evaluated by challenging encapsulated tissue microstructures, with either activator (17- $\beta$-estradiol) or inhibitor (fulvestrant) molecules. Our results show differential expression of $P G R, A R E G$ and $p S 2$ in tissue microstructures originated from different $\mathrm{ER}+\mathrm{BC}$ patients, suggesting that the model reflects inter-patient heterogeneity. This may be in terms of basal expression levels of the target genes analyzed, ER transcriptional response and potential presence of ER-independent regulatory pathways $[4,61] . p S 2$ is a wellknown direct downstream ER $\alpha$ target, which is under the positive control of an ERE consensus sequence located 400 bp before transcription starting site [62]. Our results show a higher upregulation of $p S 2$ when comparing with $A R E G$ and PGR. In fact, it has been reported for the ER+ MCF-7 $\mathrm{BC}$ cell line that, upon estrogen exposure, $p S 2$ expression strongly increases compared to $P G R$, at mRNA and also at protein levels [63, 64]. We have also observed the effects of fulvestrant at the level of ER $\alpha$ protein, as the drug is described to accelerate ER $\alpha$ degradation [32].

Aiming to retain ER+ cells, we employed a culture medium enriched in molecules with reported ER stimulatory effects, such as insulin, hydrocortisone and EGF [15-20]. 17- $\beta$-estradiol and EGF may also be produced by the breast fibroblasts present in culture [65-67]. Our observation of reduced effects upon 17- $\beta$-estradiol stimulation in tissue microstructures cultured in complete medium compared with tissue microstructures cultured in depleted medium in the 3 days preceding stimulation, corroborates the presence of soluble ER activators in culture. Further studies are required to understand the signaling events that contribute to the maintenance of ER $\alpha$ signaling under the culture conditions here presented, which will potentially also contribute to further disclose its role in ER+ BC.

\section{Conclusions}

Overall, we advocate a new methodology for ER+ BC TME modelling, in which the original cell populations, the native ECM and tissue architecture are represented, and ER function sustained. This ex vivo culture system can contribute to the study of breast cancer biology, in particular ER $\alpha$ signaling and microenvironmental-driven molecular mechanisms. Moreover, due to the extended culture time, the system can be a useful tool to study novel anti-endocrine therapies and other therapeutic modalities.

\section{Supplementary information}

Supplementary information accompanies this paper at https://doi.org/10. 1186/s13046-020-01653-4.

Additional file 1: Figure S1. Sample weight.

Additional file 2: Figure S2. a Metabolic activity was assessed along culture. b Immunohistochemistry analysis of p63 (myoepithelial cells) at 1 
month of culture (scale bar: $60 \mu \mathrm{m})$. c Metabolic activity was assessed in encapsulated and non-encapsulated tissue microstructures derived from the same patients.

Additional file 3: Figure S3. a Hematoxylin and eosin staining and immunohistochemistry for ERa of MDA-MB-231 (ER-negative cell line) cells cultured in 2D (scale: $200 \mu \mathrm{m}$ ). b ERa gene (ESR1) expression in encapsulated microstructures cultured for 1 month relatively to MDA-MB231 cells.

Additional file 4: Figure S4. a Encapsulated tissue microstructures were cultured for 3 days in depleted medium before stimulation with 17$\beta$-estradiol; expression of ER downstream target genes was assessed by RT-qPCR (amphiregulin - AREG, progesterone receptor - PGR and protein PS2 - pS2, N =9); quantitative evaluation of data shown in Fig. 3b). b Correlation diagrams of expression of ERa gene (ESR1) and ER target genes ( $P G R, p S 2$ and AREG). The dots represent the log (mRNA fold change relative to control) of each gene for a given $B C$ patient microtissue and the lines represent the linear regression (Pearson correlation with $R$ indicated in each graph). For all cases, no significant correlation was found ( $p$ value > 0.7).c ER-negative BC encapsulated tissue microstructures cultured in complete medium were challenged with 17- $\beta$-estradiol and expression of ER downstream target genes was assessed by RT-qPCR (AREG, PGR pS2, $N=2)$. d Encapsulated tissue microstructures cultured in complete medium were challenged with 17- $\beta$-estradiol and ER downstream target genes were assessed by RT-qPCR (AREG, $P G R$ and $p S 2, N=7$ ). Data are shown as fold-change in gene expression upon $17-\beta$-estradiol challenge relatively to vehicle-exposed control (CTRL).

Additional file 5: Figure S5. Encapsulated tissue microstructures were cultured for 3 days in depleted medium before stimulation with 17- $\beta$ estradiol; expression of ER downstream target genes was assessed by RTqPCR (amphiregulin - AREG, progesterone receptor - $P G R$ and protein PS2 - $p$ S2). Data is presented individually for each tumor.

Additional file 6: Figure S6. Encapsulated tissue microstructures were cultured for 3-5 days in complete medium, before challenge with fulvestrant for 2 weeks; ERa protein was detected by western blot; $\beta$ tubulin was used as loading control $(N=3$, representative blot out of 2 technical replicates).

Additional file 7: Table S1. Immunohistochemistry analysis: reagents and conditions.

Additional file 8: Table S2. RT-qPCR analysis: primer sequences.

\section{Abbreviations}

AREG: Amphiregulin; BC: Breast cancer; CTRL: Control; ERa: Estrogen receptor a; ER+ BC: Estrogen receptor a-positive breast cancer; H\&E: Hematoxylin and eosin; IHC: Immunohistochemistry; PRG: Progesterone; SHG: Second harmonic generation; TME: Tumor microenvironment; TPEF: Two-photonexcited fluorescence

\section{Acknowledgments}

We grateful acknowledge Dr. Elizabeth Anderson for scientific advice and fruitful discussion. The Histopathology Unit at Instituto Gulbenkian Ciência, Oeiras, Portugal, is acknowledged for technical support.

\section{Authors' contributions}

MFE, CBrisken, PMA, CBrito: study conceptualization. ALC, MFE, GD, GS, CBrito: experimental design. ALC, MFE, GD, RR, FS, EG: data acquisition. ALC, MFE, GD, EG, SA and CBrito: Data analysis. ALC, MFE, GD, SA and CBrito: data interpretation. PLA, SA, PMA, CBrito: resources. ALC, MFE and CBrito: Manuscript preparation. ALC, MFE, GD, RR, FS, EG, PLA, GS, CBrisken, PMA, SA and CBrito: manuscript revision and editing. All authors read and approved the final manuscript.

\section{Funding}

We acknowledge funding sources: Fundação para a Ciência e Tecnologia (FC) for the PhD fellowships SFRH/BD/52208/2013 and PD/BD/114047/2015; iNOVA4Health (UIDB/04462/2020), a program financially supported by FCT/ Ministry of Education and Science, Portugal, through national funds and cofunded by FEDER under the PT2020 Partnership Agreement; "The Discoveries Centre for Regenerative and Precision Medicine" (European Commission
Horizon 2020 Research and Innovation programme, under the Grant Agreement number 739572); iBETXplore starting grant (3D-ABC-PI-717); the Spanish Ministry of Economy and Competitiveness through the "Severo Ochoa" program for Centres of Excellence in R\&D (SEV-2015-0522); Fundació Privada Cellex; Fundació Mir-Puig; Generalitat de Catalunya through the CERCA program"; European Commission Horizon 2020 LASERE LAB Europe (grant agreement 654148); the Biltema and ISREC Foundation; CANCERA-Paulssons.

\section{Availability of data and materials}

All data generated or analyzed during this study are included in this published article (and its supplementary information files).

\section{Ethics approval and consent to participate}

All procedures performed in studies involving human participants were in accordance with the ethical standards of the institutional and/or national research committee. Informed consent was obtained from all individual participants included in the study. Anonymized patient tumor samples were obtained from the IPOLFG after institutional review board approval (UIC/ 1088).

\section{Consent for publication}

All authors have given consent for publication.

\section{Competing interests}

The authors declare that they have no competing interests.

\section{Author details}

${ }^{1}$ iBET, Instituto de Biologia Experimental e Tecnológica, Oeiras, Portugal. ${ }^{2}$ Instituto de Tecnologia Química e Biológica António Xavier, Oeiras, Portugal. ${ }_{3}^{3}$ PPOLFG, Instituto Português de Oncologia de Lisboa Francisco Gentil, Lisbon, Portugal. ${ }^{4}$ CEDOC, Chronic Diseases Research Centre, NOVA Medical School, Universidade NOVA de Lisboa, Lisbon, Portugal. ${ }^{5}$ ICFO, Institut de Ciències Fotòniques, The Barcelona Institute of Science and Technology, Castelldefels, Barcelona, Spain. ${ }^{6}$ Swiss Institute for Experimental Cancer Research, School of Life Sciences, Ecole polytechnique fédérale de Lausanne (EPFL), Lausanne, Switzerland.

Received: 31 March 2020 Accepted: 23 July 2020

Published online: 17 August 2020

\section{References}

1. Noone A, Cronin KA, Altekruse SF, Howlader N, Lewis R, Petkov VI, et al. Cancer incidence and survival trends by subtype using data from the surveillance epidemiology and end results program, 1992-2013. Cancer Epidemiol Biomark Prev. 2017;26(4):1-19.

2. Diaz Bessone Ml, Gattas MJ, Laporte T, Tanaka M, Simian M. The tumor microenvironment as a regulator of endocrine resistance in breast Cancer. Front Endocrinol (Lausanne). 2019:10(August):1-10.

3. Rothenberger NJ, Somasundaram A, Stabile LP. The role of the estrogen pathway in the tumor microenvironment. Int J Mol Sci. 2018;19:2.

4. Martelotto LG, Ng CKY, Piscuoglio S, Weigelt B, Reis-filho JS. Breast cancer intra-tumor heterogeneity. Breast Cancer Res. 2014;16(R48):1-11.

5. Antoni D, Burckel H, Josset E, Noel G. Three-dimensional cell culture: a breakthrough in vivo. Int J Mol Sci. 2015;16:5517-27.

6. Sflomos G, Dormoy V, Metsalu T, Jeitziner R, Battista L, Scabia V, et al. A preclinical model for ERa-positive breast Cancer points to the epithelial microenvironment as determinant of luminal phenotype and hormone response. Cancer Cell. 2016;29(3):407-22.

7. Tanos T, Sflomos G, Echeverria PC, Ayyanan A, Gutierrez M, Delaloye J, et al. Progesterone / RANKL is a major regulatory Axis in the human breast. Sci Transl Med. 2013;5(182):1-10.

8. Muraro MG, Muenst S, Mele V, Quagliata L, lezzi G, Tzankov A, et al. Ex-vivo assessment of drug response on breast cancer primary tissue with preserved microenvironments. Oncoimmunology. 2017;6(7):1-12.

9. van der Kuip H, Mürdter TE, Sonnenberg M, McCellan M, Gutzeit S, Gerteis A, et al. Short term culture of breast cancer tissues to study the activity of the anticancer drug taxol in an intact tumor environment. BMC Cancer. 2006;6:1-11.

10. Naipal KAT, Verkaik NS, Sánchez H, van Deurzen CHM, den Bakker MA, Hoeijmakers JHJ, et al. Tumor slice culture system to assess drug response of primary breast cancer. BMC Cancer. 2016;16(1):1-13. 
11. Campuzano S, Pelling AE. Scaffolds for 3D cell culture and cellular agriculture applications derived from non-animal sources. Front Sustain Food Syst. 2019;3(May):1-9.

12. Rebelo SP, Pinto C, Martins TR, Harrer N, Estrada MF, Loza-Alvarez P, et al. 3D-3-culture: a tool to unveil macrophage plasticity in the tumour microenvironment. Biomaterials. 2018;163:185-97.

13. Estrada MF, Rebelo SP, Davies EJ, Pinto MT, Pereira H, Santo VE, et al. Modelling the tumour microenvironment in long-term microencapsulated $3 \mathrm{D}$ co-cultures recapitulates phenotypic features of disease progression. Biomaterials. 2016;78:50-61.

14. Mathew M, Santos SICO, Zalvidea D, Loza-Alvarez P. Multimodal optical workstation for simultaneous linear, nonlinear microscopy and nanomanipulation: upgrading a commercial confocal inverted microscope. Rev Sci Instrum. 2009;80(7):1-11.

15. Kato S, Endoh H, Masuhiro Y, Kitamoto T, Uchiyama S, Sasaki H, et al. Activation of the Estrogen Receptor Through Phosphorylation by MitogenActivated Protein Kinase. Science (80- ). 1999;270:102-6.

16. Moerkens M, Zhang Y, Wester L, van de Water B, Meerman JHN. Epidermal growth factor receptor signalling in human breast cancer cells operates parallel to estrogen receptor a signalling and results in tamoxifen insensitive proliferation. BMC Cancer. 2014;14(1):1-16.

17. Karmakar S, Jin Y, Nagaich AK. Interaction of glucocorticoid receptor (GR) with estrogen receptor (ER) $a$ and activator protein 1 (AP1) in dexamethasonemediated interference of ERa activity. J Biol Chem. 2013;288(33):24020-34.

18. Lanzino M, Morelli C, Garofalo C, Panno ML, Mauro L, Ando S, et al. Interaction between estrogen receptor alpha and insulin/IGF signaling in breast cancer. Curr Cancer Drug Targets. 2008:8(7):597-610.

19. Universi- JH, Chemistry HB. Ligand-independent activation of steroid hormone receptors. J Mol Med. 1998:469-79.

20. Chen D, Washbrook E, Sarwar N, Bates GJ, Pace PE, Thirunuvakkarasu V, et al. Phosphorylation of human estrogen receptor a at serine 118 by two distinct signal transduction pathways revealed by phosphorylation-specific antisera. Oncogene. 2002;21(32):4921-31.

21. Dolfi SC, Jäger AV, Medina DJ, Haffty BG, Yang J, Hirshfield KM. Fulvestrant treatment alters MDM2 protein turnover and sensitivity of human breast carcinoma cells to chemotherapeutic drugs. Cancer Lett. 2014;350(1-2):52-60.

22. Regan RMO, Osipo C, Ariazi E, Lee ES, Meeke K, Morris C, et al. Development and therapeutic options for the T reatment of Raloxifene-stimulated breast Cancer in Athymic mice. Cancer Ther Preclin. 2006;12(7):2255-64.

23. Domenici G, Aurrekoetxea-Rodríguez I, Simões BM, Rábano M, Lee SY, Millán JS, et al. A Sox2-Sox9 signalling axis maintains human breast luminal progenitor and breast cancer stem cells. Oncogene. 2019;38(17):3151-69.

24. Dai $X$, Cheng H, Bai Z, Li J. Breast Cancer cell line classification and its relevance with breast tumor subtyping. J Cancer. 2017;8(16):3131-41.

25. Livak KJ, Schmittgen TD. Analysis of relative gene expression data using real- time quantitative PCR and the 2/deltadeltaCt method. Methods. 2001; 25(4):402-8.

26. Matthew G, Heiden V, Cantley LC, Thompson CB. Understanding the Warburg Effect: The Metabolic Requirements of Cell Proliferation. Science (80- ). 2010;324(5930):1029-33.

27. Gloushankova NA, Rubtsova SN, Zhitnyak IY. Cadherin-mediated cell-cell interactions in normal and cancer cells. Tissue Barriers. 2017;5(3):1-15.

28. Altin JG, Sloan EK. The role of CD45 and CD45-associated molecules in T cell activation. Immunol Cell Biol. 1997;75(5):430-45.

29. Buisseret L, Garaud S, De WA, Van Den EG, Boisson A, Solinas C. Tumorinfiltrating lymphocyte composition, organization and PD-1 / PD-L1 expression are linked in breast cancer, vol. 6; 2017. p. 1.

30. Holl EK, Frazier VN, Landa K, Beasley GM, Hwang ES, Nair SK. Examining peripheral and tumor cellular Immunome in patients with Cancer. Front Immunol. 2019;10(July):1767.

31. Garaud S, Buisseret L, Solinas C, Gu-Trantien C, De Wind A, Van Den Eynden $\mathrm{G}$, et al. Tumor-infiltrating B cells signal functional humoral immune responses in breast cancer. JCI Insight. 2019;4:18.

32. Osborne CK, Wakeling A, Nicholson RI. Fulvestrant: an oestrogen receptor antagonist with a novel mechanism of action. Br J Cancer. 2004;90:2-6.

33. Vergote I, Robertson JFR. Fulvestrant is an effective and well-tolerated endocrine therapy for postmenopausal women with advanced breast cancer: results from clinical trials. Br J Cancer. 2004:90:S11-4.

34. Amir E, Miller N, Geddie W, Freedman O, Kassam F, Simmons C, et al. Prospective study evaluating the impact of tissue confirmation of metastatic disease in patients with breast Cancer. J Clin Oncol. 2020;30(6):587-92.
35. Burns KA, Korach KS. Estrogen receptors and human disease: an update. Arch Toxicol. 2016:86(10):1491-504.

36. Lindstro LS, Karlsson E, Wilking UM, Johansson U, Hartman J, Lidbrink EK, et al. Clinically Used Breast Cancer Markers Such As Estrogen Receptor, Progesterone Receptor, and Human Epidermal Growth Factor Receptor 2 Are Unstable Throughout Tumor Progression. J Clin Oncol. 2020;30:21.

37. Pontiggia O, Sampayo R, Raffo D, Motter A, Xu R, Bissell MJ, et al. The tumor microenvironment modulates tamoxifen resistance in breast cancer: a role for soluble stromal factors and fibronectin through $\beta 1$ integrin. Breast Cancer Res Treat. 2012;133(2):459-71.

38. Brechbuhl HM, Finlay-schultz J, Yamamoto TM, Gillen AE, Cittelly DM, Tan $A C$, et al. Fibroblast subtypes regulate responsiveness of luminal breast cancer to estrogen. Clin Cancer Res. 2018;23(7):1710-21.

39. Morgan MM, Livingston MK, Warrick JW, Stanek EM, Alarid ET, Beebe DJ, et al. Mammary fibroblasts reduce apoptosis and speed estrogeninduced hyperplasia in an organotypic MCF7-derived duct model. Sci Rep. 2018;8(1):1-13.

40. Jansen MPHM, Foekens JA, Van Staveren IL, Dirkzwager-Kiel MM, Ritstier K, Look MP, et al. Molecular classification of tamoxifen-resistant breast carcinomas by gene expression profiling. J Clin Oncol. 2005;23(4):732-40.

41. Sampayo RG, Toscani AM, Rubashkin MG, Thi K, Masullo LA, Violi IL, et al. Fibronectin rescues estrogen receptor a from lysosomal degradation in breast cancer cells. J Cell Biol. 2018;217(8):2777-98.

42. Alco GUL, An ABG, Lu DSG, Pilanci KNUR, Tuzlali S, Ordu C, et al. Clinical and histopathological factors associated with Ki-67 expression in breast cancer patients. Oncol Lett. 2015;9:1046-54.

43. Davies EJ, Dong M, Gutekunst M, Närhi K, Van Zoggel HJAA, Blom S, et al. Capturing complex tumour biology in vitro: histological and molecular characterisation of precision cut slices. Sci Rep [Internet]. 2015;5(July):1-17 Available from: https://doi.org/10.1038/srep17187.

44. Mekala NK, Baadhe RR, Potumarthi R. Mass transfer aspects of 3D cell cultures in tissue engineering. Asia-Pacific J Chem Eng. 2014;9(3):318-29.

45. Rouwkema J, Koopman BFJM, Blitterswijk CAV, Dhert WJA, Malda J. Supply of nutrients to cells in engineered tissues. Biotechnol Genet Eng Rev. 2009; 26(1):163-78.

46. Sun J, Tan H. Alginate-Based Biomaterials for Regenerative Medicine Applications. Materials (Basel). 2013;6:1285-309.

47. Wilson JL, Najia MA, Saeed R, McDevitt TC. Alginate encapsulation parameters influence the differentiation of microencapsulated embryonic stem cell aggregates. Biotechnol Bioeng. 2014;111(3):618-31.

48. Miranda JP, Rodrigues A, Tostões RM, Sofia Leite HZ, Carrondo MJT, Alves PM. Extending Hepatocyte Functionality for Drug-Testing Applications Using High-Viscosity Alginate-Encapsulated Three-Dimensional Cultures in Bioreactors. Tissue Eng Part C Methods. 2010;16(6)

49. Kanta J. Collagen matrix as a tool in studying fibroblastic cell behavior. Cell Adhes Migr. 2015;9(4):308-16.

50. Tilbury K, Campagnola PJ. Applications of second-harmonic generation imaging microscopy in ovarian and breast cancer. Perspect Medicin Chem. 2015;7:21-32.

51. Provenzano PP, Inman DR, Eliceiri KW, Knittel JG, Yan L, Rueden CT, et al. Collagen density promotes mammary tumor initiation and progression. BMC Med. 2008;6:1-15

52. Li T, Sun L, Miller N, Nicklee T, Woo J, Hulse-Smith L, et al. The association of measured breast tissue characteristics with mammographic density and other risk factors for breast cancer. Cancer Epidemiol Biomark Prev. 2005; 14(2):343-9.

53. Netti PA, Berk DA, Swartz MA, Grodzinsky AJ, Jain RK. Role of extracellular matrix assembly in interstitial transport in solid tumors. Cancer Res. 2000; 60(9):2497-503

54. Rijal G. Native-mimicking in vitro microenvironment: an elusive and seductive future for tumor modeling and tissue engineering. J Biol Eng. 2018:1-22.

55. Stanton SE, Disis ML. Clinical significance of tumor-infiltrating lymphocytes in breast cancer. J Immunother Cancer [Internet]. 2016:4(1):1-7. Available from:. https://doi.org/10.1186/s40425-016-0165-6.

56. Wang $X$, Mori I, Tang W, Nakamura M, Nakamura $Y$, Sato M. p63 Expression in Normal, Hyperplastic and Malignant Breast Tissues. Breast cancer 2002:9(3):0-3.

57. Ribeiro-silva A, Ramalho LNZ. The relationship between p63 and p53 expression in Normal and neoplastic breast tissue. Arch Pathol Lab Med. 2003;127(3):336-40. 
58. Makki J. Diversity of breast carcinoma: histological subtypes and clinical relevance. Clin Med Insights Pathol. 2015;8(1):23-31.

59. Kang KS, Morita I, Cruz A, Jeon YJ, Trosko JE, Chang CC. Expression of estrogen receptors in a normal human breast epithelial cell type with luminal and stem cell characteristics and its neoplastically transformed cell lines. Carcinogenesis. 1997;18(2):251-7.

60. Jia M, Dahlman-Wright K, Gustafsson JÅ. Estrogen receptor alpha and beta in health and disease. Best Pract Res Clin Endocrinol Metab. 2015;29(4):557-68.

61. Lindstro LS, Yau C, Czene K, Thompson CK, Hoadley KA, Van Veer L, et al. Intratumor heterogeneity of the estrogen receptor and the long-term risk of fatal breast Cancer. JNCI J Natl Cancer Inst. 2018;110(7):726-33.

62. Lin C-Y, Ström A, Vega VB, Kong SL, Yeo AL, Thomsen JS, et al. Discovery of estrogen receptor alpha target genes and response elements in breast tumor cells. Genome Biol. 2004;5(9):R66.

63. Kim J, Lee J, Jang SY, Kim C, Choi Y, Kim A. Anticancer effect of metformin on estrogen receptor-positive and tamoxifen-resistant breast cancer cell lines. Oncol Rep. 2016;35(5):2553-60.

64. Fleury L, Gerus M, Lavigne AC, Richard-Foy H, Bystricky K. Eliminating epigenetic barriers induces transient hormone-regulated gene expression in estrogen receptor negative breast cancer cells. Oncogene. 2008;27(29): 4075-85.

65. Buchsbaum RJ, Oh SY. Breast cancer-associated fibroblasts: where we are and where we need to go. Cancers (Basel). 2016;8(2):1-19.

66. Kurobe M, Furukawa S, Hayashi K. Synthesis and secretion of an epidermal growth factor (EGF) by human fibroblast cells in culture. Biochem Biophys Res Commun. 1985:131(3):1080-5.

67. Majety M, Pradel LP, Gies M, Ries CH. Fibroblasts influence survival and therapeutic response in a 3D co-culture model. PLoS One. 2015;10(6):1-18,

\section{Publisher's Note}

Springer Nature remains neutral with regard to jurisdictional claims in published maps and institutional affiliations.

Ready to submit your research? Choose BMC and benefit from:

- fast, convenient online submission

- thorough peer review by experienced researchers in your field

- rapid publication on acceptance

- support for research data, including large and complex data types

- gold Open Access which fosters wider collaboration and increased citations

- maximum visibility for your research: over $100 \mathrm{M}$ website views per year

At $\mathrm{BMC}$, research is always in progress.

Learn more biomedcentral.com/submissions 